\title{
PEMANFAATAN BATANG PISANG UNTUK ANEKA PRODUK MAKANAN OLAHAN DI KECAMATAN JENAWI, KARANGANYAR
}

\author{
Retno Rosariastuti", Sumani, Aktavia Herawati \\ Program Studi Ilmu Tanah, Fakultas Pertanian Universitas Sebelas Maret, Surakarta \\ *Email : retnobs@staff.uns.ac.id
}

\begin{abstract}
ABSTRAK
Kecamatan Jenawi, merupakan salah satu kecamatan yang berada di wilayah Kabupaten Karanganyar. Fakultas Pertanian Universitas Sebelas Maret, Surakarta telah menjadikan kecamatan ini sebagai lokasi pilot project penanaman tanaman pisang hasil kultur jaringan, produksi dosen Fakultas Pertanian UNS. Oleh sebab itu di Jenawi dijumpai banyak tanaman pisang yang tumbuh dengan baik dengan produksi buah yang melimpah. Program IbM yang dilaksanakan ini merupakan program pengabdian kepada masyarakat yang dilaksanakan di Kelompok Wanita Tani Rejeki Mandiri dan Mukti Rahayu di Kecamatan Jenawi. Salah satu bagian tanaman yang pemanfaatannya masih sangat terbatas adalah batang pisang, khususnya bagian dalam yang berwarna putih, yang biasa disebut hati batang pisang. Permasalahan yang dijumpai adalah bahwa masyarakat di kecamatan Jenawi belum mengenal teknologi/cara pembuatan kerupuk dan dendeng berbahan dasar hati batang pisang. Melalui pembuatan kerupuk dan dendeng hati batang pisang, masyarakat dapat meningkatkan kemanfaatan tanaman pisang, dan dapat digunakan sebagai alternatif mata pencaharian baru. Hasil yang telah dicapai dalam kegiatan ini yaitu Pelatihan Tahap I berupa pembuatan kerupuk dan dendeng dari hati pisang yang telah dilaksanakan pada tanggal 9 Agustus 2017 pada 2 Kelompok Wanita Tani (KWT).Antusiasme tampak terlihat dari peserta yang mayoritas merupakan ibu rumah tangga. Kegiatan ini dihadiri sekitar 50 orang peserta, pamong desa dan penyuluh pertanian. Dalam kegiatan ini juga diberikan bantuan kepada kedua KWT berupa oven gas, blender, wajan, baskom serta bahan-bahan keperluan pembuatan kerupuk dan dendeng. Pelatihan Tahap II dilaksanakan pada tanggal 8 September 2017 dengan agenda menguji kualitas baik dari segi rasa, bentuk dan gizi dari hasil olahan kerupuk dan dendeng tersebut. Kerupuk hati batang pisang hasil olahan ke dua KWT peserta pelatihan, telah memenuhi standar kerupuk pada umumnya yaitu renyah, dan gurih. Sedangkan produk olahan dendeng juga sudah menyerupai dendeng yang berbahan dasar daging sapi, hanya saja dari segi warna kurang mengkilap karena serat hati batang pisang tidak mengandung lemak. Oleh sebab itu ke dua jenis makanan hasil olahan hati batang pisang, utamanya kerupuk, dengan kemasan yang menarik siap diproduksi masal untuk dipasarkan secara luas. Kerupuk hati batang pisang dapat menjadi alternatif makanan camilan, dengan menambah perasa makanan seperti keju, bumbu barbeque, lada hitam, dan lain-lain.
\end{abstract}

Kata kunci: hati batang pisang, kerupuk, dendeng, pelatihan, kelompok wanita tani

\section{PENDAHULUAN}

Tanaman pisang (Musa paradisiaca L.) merupakan tumbuhan yang banyak tumbuh didaerah tropis, karena menyukai iklim panas dan memerlukan matahari penuh. Tanaman ini dapat tumbuh di tanah yang cukup air pada daerah dengan ketinggian sampai 2000 meter di atas permukaan laut.Di Indonesia, tanaman pisang dapat dijumpai di hampir semua daerah. Hampir semua bagian tanaman pisang dapat dimanfaatkan, namun utamanya yang dimanfaatkan adalah buahnya. Buah pisang rasanya manis, beberapa jenis pisang berasa sedikit asam, sehingga disukai oleh hampir seluruh 
masyarakat di dunia. Di Indonesia, buah pisang umumnya dimakan segar, dibuat kolak, di kukus, atau diolah lebih lanjut menjadi pisang selai, keripik, tepung pisang, dan lain-lain. Buah pisang dapat dikelompokkan ke dalam beberapa kelompok berdasarkan pemanfaatannya.Kelompok pertama adalah Musa sapientum (banana)yang termasuk pisang buah meja. Kelompok ini lebih enak dimakan segar. Anggota kelompok ini antara lain :pisang ambon, ambon lumut, raja, raja sereh, mas, susu, dan barangan. Kelompok ke dua adalah Musa paradisiaca (plantain).Buah pisang pada kelompok ini lebih enak setelah diolah terlebih dahulu.Anggota kelompok ini antara lain : pisang tanduk, oli, nangka, kapas, batu, dan kepok. Kelompok ke tiga adalah Musa brachycarpa, yaitu jenis pisang yang berbiji seperti pisang batu, disebut juga pisang klutuk.Kelompok ke empat adalah Musa texilis, yaitu jenis pisang penghasil serat seperti pisang manila.

Beberapa manfaat buah pisang pada kesehatan manusia antara lain :melumas (lubricate) usus, penawar racun, penurun panas (antipiretik), antiradang, peluruh kencing (diuretik), laksatif dingin dan lainlain.Buah pisang mengandung banyak vitamin (diantaranya vitamin $\mathrm{C}$ dan $\mathrm{D}$ ) dan mineral (diantaranya Kalsium, Potasium dan Fosfor), sehingga sangat bermanfaat dalam menjaga kesehatan manusia, sebab dapat meningkatkan daya tahan tubuh yang mengkonsumsinya, sehingga mengurangi resiko terserang penyakit. Tingginya nilai gizi buah pisang disertai seratnya yang halus, menyebabkan buah ini sangat baik digunakan sebagai makanan bayi, balita maupun lansia. Buah pisang juga baik untuk para penderita sakit yang sedang dalam proses penyembuhan. Kandungan karbohidrat (gula) dan fosfor dalam buah pisang akan membuat yang mengkonsumsinya tahan lapar, namun bagi penderita tukak lambung dan asam lambung berlebihan disarankan untuk tidak mengkonsumsi buah pisang masak secara berlebihan, terlebih ketika perut dalam keadaan kosong (Afandi 2013; Anonim 2015).

Bagian tanaman pisang yang dapat dimanfaatkan selain buahnya adalah :

1. Daun.

Daun pisang dikenal sebagai bahan pembungkus makanan sejak lama dan sebagai bagian dari ritual budaya, misal sebagai alas pada penyajian nasi tumpeng atau sesaji.

2. Batang pisang (gedebog)

Batang pisang dapat digunakan sebagai bahan pembuat rakit, mainan anak-anak, sarana ritual budaya (misal alat untuk menancapkan wayang kulit), seratnya sebagai bahan dasar industri tekstil,

3. Jantung (bunga) pisang

Jantung pisang dapat digunakan sebagai bahan makanan olahan dan sarana pembuatan mainan anak-anak

4. Bonggol pisang

Bila bagian tengah bonggol pisang yang masih berada di tanah dilubangi, akan mengeluarkan air, yang mana air ini sering dimanfaatkan sebagai penyubur rambut, dan antiseptic pada luka.

5. Akar pisang

Akar pisang dan hati batang pisang dapat digunakan sebagai sumber mikroorganisma pada pembuatan pupuk hayati.

6. Kulit buah pisang

Ada sebagian masyarakat yang memanfaatkan kulit buah pisang sebagai campuran masakan.

Berdasarkan uraian di depan, diketahui begitu banyak manfaat dari tanaman pisang, namun sebenarnya masih banyak potensi pemanfaatan dari tanaman pisang, utamanya pada bagian hati batang pisang. Hati batang pisang sangat besar manfaatnya untuk digunakan sebagai bahan dasar makanan olahan, yaitu sebagai bahan dasar pembuatan 
kerupuk dan dendeng. Kerupuk dan dendeng hati batang pisang saat ini belum dikenal secara luas oleh masyarakat, padahal dengan cara memasak dan pemberian bumbu yang tepat, akan tercipta kerupuk dan dendeng hati batang pisang yang enak dan prospektif dikembangkan sebagai alternatif produk makanan baru. Tingginya serat pada hati batang pisang, akan menyebabkan ke dua produk makanan tersebut memiliki kandungan serat yang tinggi, sehingga baik untuk pencernaan. Deversifikasi pemanfaatan hati batang pisang sebagai bahan dasar pembuatan makanan olahan, akan meningkatkan nilai tambah dari tanaman pisang, utamanya secara ekonomi, apalagi jika teknologi yang digunakan tergolong sederhana. Untuk itu perlu pengenalan cara pembuatan kerupuk dan dendeng hati batang pisang ini kepada masyarakat yang di lingkungannya banyak tumbuh tanaman pisang, khususnya masyarakat pedesaan.

Kecamatan Jenawi, Kab. Karanganyar, Propinsi Jawa Tengah merupakan salah satu wilayah yang banyak ditumbuhi tanaman pisang. Fakultas Pertanian Universitas Sebelas Maret telah menggunakan wilayah ini sebagai pilot project penanaman pisang hasil kultur jaringan yang dilakukan oleh staf dosen di fakultas ini. Oleh sebab itu sebagai tindak lanjut dari kegiatan yang telah dilakukan oleh FP UNS, perlu kiranya upaya pemanfaatan tanaman pisang sebesarbesarnya, agar masyarakat setempat dapat memetik hasil dari penanaman tanaman pisang tersebut dengan meningkatnya pendapatan masyarakat. Kegiatan pengenalan cara dan praktek pembuatan kerupuk dan dendeng hati batang pisang telah dilakukan kantor Balai Penyuluh Pertanian (BPP) Kec. Jenawi dan diikuti oleh Dua Kelompok Wanita Tani (KWT) yaitu KWT Mukti Rahayu, yang beralamat di Dusun Noyu, Desa Sidomukti, (Ketua Ibu Yani), dan
KWT Rejeki Mandiri, yang beralamat di Desa Menjing (Ketua Sularmi).

Tujuan kegiatan ini antara lain : 1 . menawarkan alternatif pemanfaatan hasil pertanian menjadi produk pangan baru yang belum dikenal luas oleh masyarakat, harapannya, kegiatan ini dapat mendukung program pemerintah dalam hal ketahanan dan keamanan pangan, 2 . meningkatkan ketrampilan masyarakat dalam pengolahan hasil pertanian menjadi produk pangan baru menggunakan teknologi sederhana, 3. meningkatkan diversifikasi pemanfaatan tanaman pisang, 4. meningkatkan nilai kemanfaatan dan nilai ekonomis batang tanaman pisang sebagai sumber bahan makanan olahan baru, dari semula tidak lazim digunakan sebagai bahan baku makanan olahan menjadi bahan baku pembuatan kerupuk dan dendeng hati batang pisang yang bernilai ekonomis tinggi, 5. meningkatkan pengetahuan dan ketrampilan masyarakat kecamatan Jenawi, Kab. Karanganyar dalam hal pemanfaatan hati batang pisang sebagai sumber bahan baku makanan olahan baru, yaitu pengolahan hati batang pisang menjadi kerupuk dan dendeng hati batang pisang. Adapun teknologi yang digunakan termasuk teknologi sederhana dan pastinya ramah Lingkungan, 6. membantu masyarakat kecamatan Jenawi dalam memanfaatkan tanaman pisangnya, selain buahnya, sehingga dapat menjadi alternatif sumber mata pencaharian baru.

\section{BAHAN DAN METODE}

\section{Tata laksana}

Tata laksana kegiatan meliputi :

1. Survei pendahuluan guna mendapatkan desa (wilayah) yang memiliki banyak tanaman pisang,

2. Koordinasi dengan perangkat desa dalam menentukan waktu, tempat dan materi yang dibutuhkan, 
3. Persiapan peralatan dan perlengkapan pelatihan,

4. Penyusunan modul/materi pelatihan

5. Praktek pembuatan kerupuk dan dendeng hati batang pisang, dengan memanfaatkan batang tanaman pisang yang tumbuh di wilayah tersebut, utamanya yang telah dipanen buahnya, dan selama ini hanya dibuang begitu saja.

\section{Metoda Pengabdian :}

Metode yang digunakan adalah partisipasi masyarakat (participatory rural appraisal). Partisipasi ke dua KWT dalam kegiatan ini adalah menyediakan bahan dasar hati batang pisang dan beberapa peralatan sederhana seperti pisau, telenan, cobek, kompor, dan dandang. Metoda pendekatan ini menekankan pada inovasi dan teknologi pembuatan kerupuk dan dendeng berbahan dasar hati batang pisang dengan menggunakan teknologi sederhana, dengan harapan aspek keberlanjutan pasca kegiatan dapat berlangsung terus. Sebelum pelatihan dimulai terlebih dahulu dijelaskan mengenai cara dan tahap-tahap pembuatan kerupuk dan dendeng berbahan dasar hati batang pisang. Setelah itu, peserta diminta untuk praktek langsung membuat kerupuk dan dendeng.

\section{Pembuatan Kerupuk Hati Batang Pisang}

1. Bahan

a. Hati batang pisang, yaitu batang pisang bagian paling dalam yang berwarna putih dengan ukuran $2 \mathrm{~m}$,

b. Tepung tapioka sebanyak $1 \mathrm{~kg}$.

c. Air secukupnya

d. Bumbu : 10 siung bawang putih, 1 sendok teh merica halus, garam, gula, dan bahan penyedap secukupnya

2. Alat

Blender, panci untuk mengukus (dandang), kain untuk menyaring, loyang untuk menjemur, wajan untuk menggoreng, telenan, pisau, dan lain-lain
3. Cara penyiapan ampas hati batang pisang:

a. Gedebok pisang, diambil bagian yang paling dalam yang berwarna putih, yang disebut hati batang pisang. Setiap $1 \mathrm{~m}$ hati batang pisang akan diperoleh kira-kira $0,5 \mathrm{~kg}$ ampas hati batang pisang.

b. Hati batang pisang dicuci bersih, kemudian iris kecil-kecil (dicacah), selanjutnya dihaluskan menggunakan blender atau peralatan penghalus lainnya,

c. Hati batang pisang yang sudah halus disaring menggunakan kain saring yang halus (kain katun), buang air perasannya. Ampas hati batang pisang yang diperoleh, siap digunakan sebagai bahan dasar pembuatan aneka makanan.

4. Cara pembuatan Kerupuk Hati Batang Pisang :

a. Tiap $1 \mathrm{~kg}$ ampas hati batang pisang dicampur dengan $1 \mathrm{~kg}$ tepung tapioca (perbandingan ampas hati batang : tepung tapioca $=1: 1$ ), masukkan pula semua bumbu yang sudah dihaluskan lebih dahulu.

b. Semua bahan yang sudah tercampur diuleni (bila terlalu kering beri air seperlunya dengan menggunakan sendok makan), sampai membentuk gumpalan yang liat berbentuk silinder, kemudian bungkus menggunakan daun pisang atau plastic. Ini merupakan bahan dasar kerupuk hati batang pisang. Kukus selama kurang lebih 11,5 jam (sampai matang), kemudian dinginkan dengan membiarkan selama 1 malam.

c. Selanjutnya bahan dasar kerupuk batang pisang diiris tipis, lalu dijemur di bawah panas matahari, hingga menjadi kerupuk hati batang pisang mentah

d. Kerupuk hati batang siap digoreng dan siap dikonsumsi 
Pembuatan Dendeng Hati Batang Pisang :

1. Bahan

a. $1 \mathrm{~kg}$ ampas hati batang pisang

b. $50-100 \mathrm{~g}$ tepung terigu sebanyak.

c. Air secukupnya

d. Madu

e. Bumbu : 4 siung bawang putih, 4 butir bawang merah, 3 buah cabe merah, 25 g ketumbar, 0,5 sendok the merica halus, $200 \mathrm{~g}$ gula merah (atau sesuai selera), 0,5 sendok makan air asam Jawa, garam, dan bahan penyedap secukupnya

2. Alat

Blender, oven, kain untuk menyaring, loyang untuk mengeringkan, wajan untuk menggoreng, telenan, pisau, dan lain-lain

3. Cara pembuatan Dendeng Hati Batang Pisang :

a. Haluskan semua bumbu hingga benarbenar halus secara merata (kecuali lengkuas dan daun salam).

b. Masukkan bumbu yang telah dihaluskan tersebut ke dalam wadah yang telah berisi ampas hati batang pisang, lalu aduk secara merata, terakhir masukkan tepungnya dan aduk lagi secara merata.

c. Setelah itu, diamkan terlebih dahulu hati batang pisang yang telah dibumbui selama kurang lebih 1-3 jam sampai bumbu meresap secara keseluruhan kedalam hati batang pisang. Peresapan bumbu akan lebih baik jika dibiarkan selama semalam, namun harus disimpan dalam lemari pendingin (kulkas) pada suhu sekitar $4-6^{\circ} \mathrm{C}$.

d. Sementara itu, siapkan loyang yang bersih.

e. Setelah proses peresapan bumbu selesai, selanjutnya ambil $1 / 4$ bagian adonan hati batang pisang, lalu letakkan di atas Loyang yang telah diberi kertas roti di atasnya, lalu di tekan-tekan hingga membentuk lembaran dengan ketebalan sekitar 2 mm. Usahakan bentuk lembarannya adalah persegi, bukan bulat.

f. Selanjutnya keringkan dalam oven dengan suhu $180^{\circ} \mathrm{C}$ selama $15-20$ menit. Selama pengeringan sesekali harus dilihat agar tidak gosong. Setelah 15 - 20 menit pertama, keluarkan loyang, lalu dendeng hati batang pisang dibalik, kemudian dipanaskan kembali selama $15-20$ menit. Setelah itu keluarkan dari oven. Dendeng hati batang pisang telah jadi.

g. Selanjutnya siapkan madu secukupnya, beri sedikit air panas, lalu olesi dendeng hati batang pisang dengan air madu tersebut agar tampak mengkilat

h. Oven kembali dendeng hati batang pisang pada suhu $180^{\circ} \mathrm{C}$, selama sekitar 5 menit.

i. Berikutnya keluarkan dendeng hati batang pisang dari oven, dan siap di potong-potong sesuai selera ketika masih hangat. Setelah itu dinginkan dan siap disantap atau dikemas.

Cara penyajian lainnya adalah dengan digoreng. Untuk itu siapkan minyak diatas wajan yang panas dan tunggu hingga minyak panas. Kemudian goreng sebentar dendeng, sehingga dendeng hati batang pisang siap untuk disantap. JANGAN MENGGORENG DENDENG TERLALU LAMA, KARENA DENDENG AKAN KERAS.

\section{HASIL YANG DICAPAI}

Berdasarkan hasil survey pada tahap awal, telah terpilih wilayah Kecamatan Jenawi sebagai lokasi kegiatan dikarenakan banyaknya tanaman pisang yang tumbuh di wilayah tersebut. Selanjutnya berdasar hasil koordinasi dengan perangkat pemerintah Kec. Jenawi dan KWT, maka ditetapkan waktu pelaksanaan pelatihan dan praktek pembuatan kerupuk dan dendeng berbahan 
dasar hati pisang tahap 1 yaitu tanggal 9 Agustus 2017 yang diikuti oleh sekitar 50 wanita tani. Selain pelatihan, diberikan juga bantuan berupa oven gas, blender, penggorengan, loyang serta beberapa baskom untuk menunjang kegiatan pembuatan makanan olahan tersebut. Pelatihan ini juga dihadiri oleh pamong desa dan Penyuluh Pertanian Kec.Jenawi. Pelatihan Tahap I baru sampai pada kegiatan produksi (mengukus dan mengoven). Pelatihan tahap II dilaksanakan pada tanggal 8 September 2017 dengan agenda monitoring dan uji kualitas baik dari segi rasa, dan bentuk dari hasil olahan kerupuk dan dendeng tersebut. Kerupuk hati batang pisang hasil olahan ke dua KWT peserta pelatihan, telah memenuhi standar kerupuk pada umumnya yaitu renyah, dan gurih. Sedangkan produk olahan dendeng juga sudah menyerupai dendeng yang berbahan dasar daging sapi, hanya saja dari segi warna kurang mengkilap karena serat hati batang pisang tidak mengandung lemak. Oleh sebab itu ke dua jenis makanan hasil olahan hati batang pisang, utamanya kerupuk, dengan kemasan yang menarik siap diproduksi masal untuk dipasarkan secara luas. Kerupuk hati batang pisang dapat menjadi alternatif makanan camilan, dengan menambah perasa makanan seperti keju, bumbu barbeque, lada hitam, dan lain-lain.

\section{Pelatihan tahap 1 :}

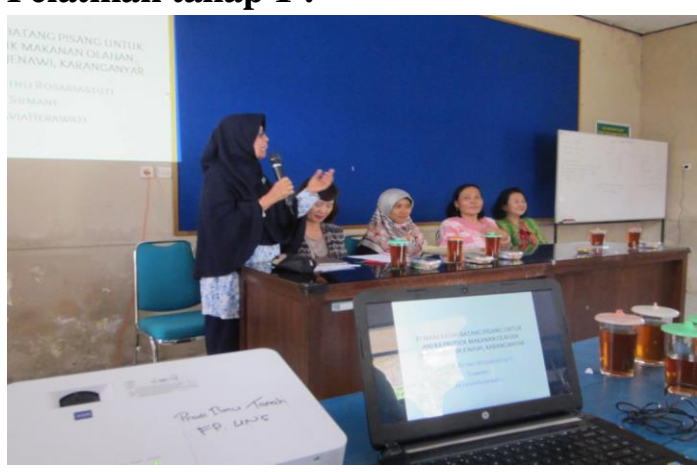

Pengenalan dan penjelasan oleh Tim Pengabdian UNS mengenai cara pembuatan kerupuk dan dendeng

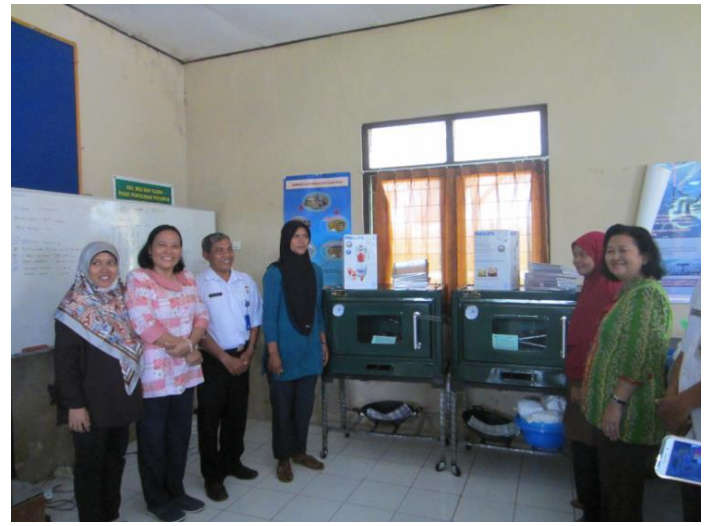

Pemberian bantuan berupa oven gas, blender, Loyang, wajan dan lain-lain dari Tim Pengabdian kepada KWT

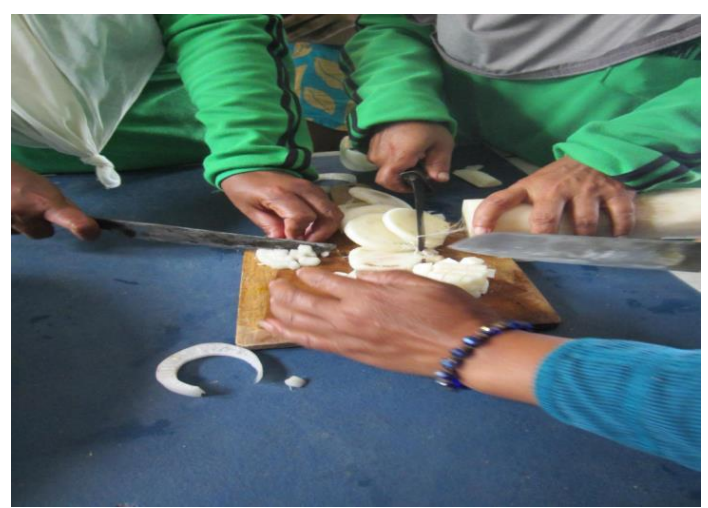

Pemotongan hati batang pisang sebagai bahan dasar pembuatan kerupuk dan dendeng

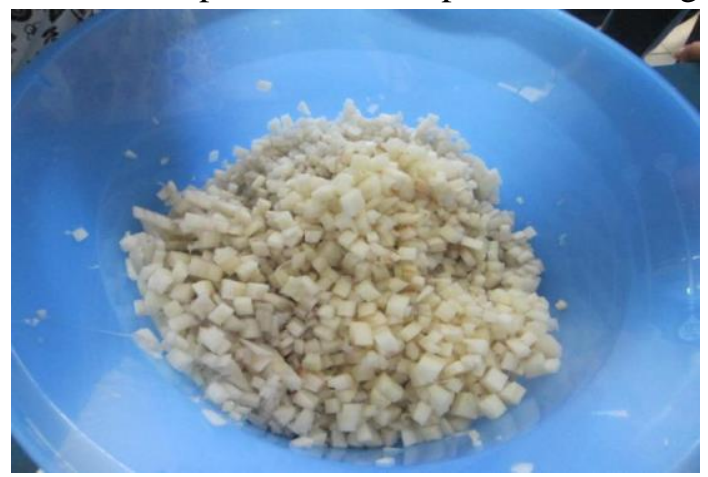

Hati batang pisang selesai dipotong dan siap diblender/dihaluskan 


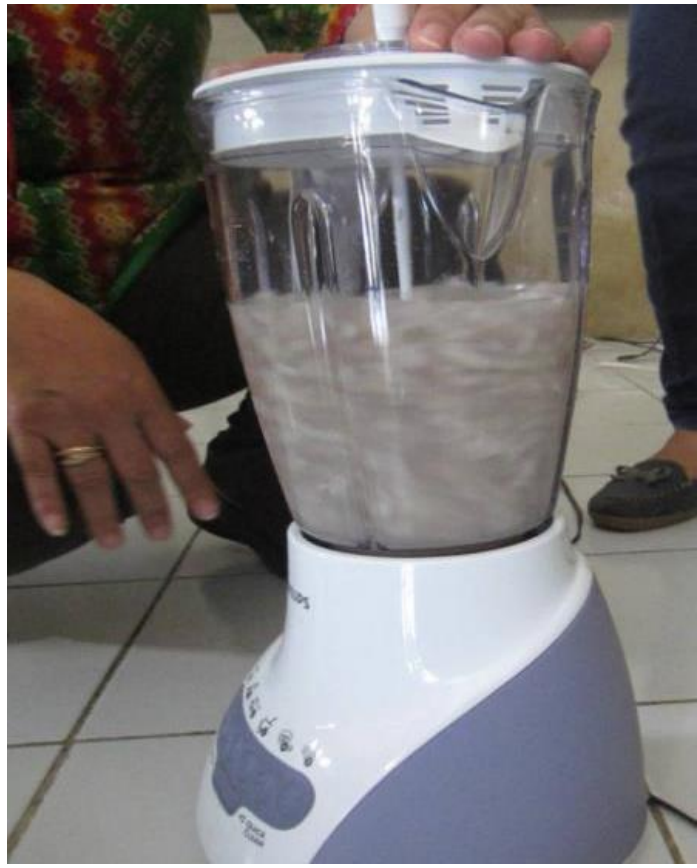

Penghalusan hati batang pisang dengan blender

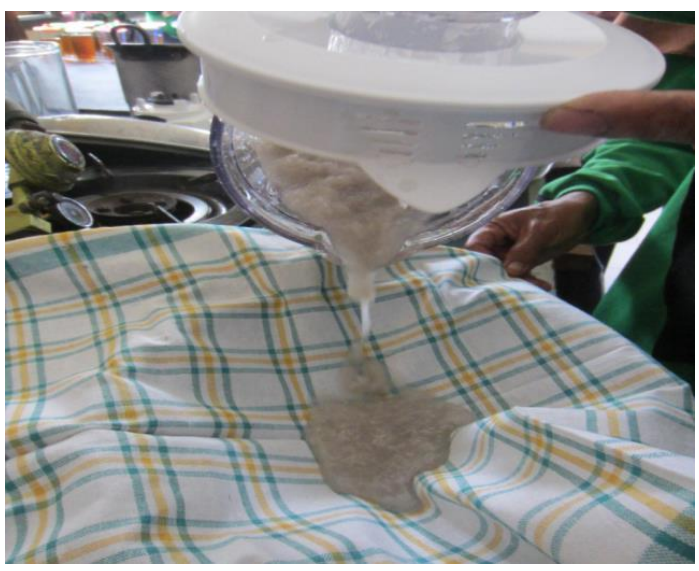

Penyaringan untuk mendapatkan ampas hati pisang

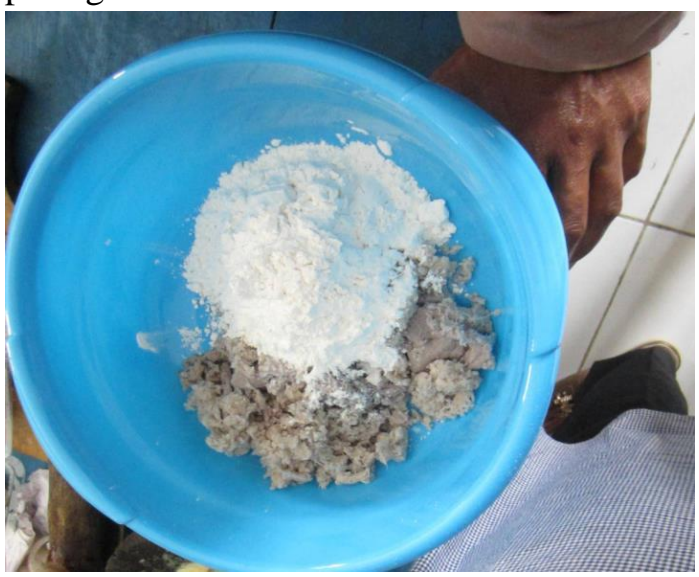

Pembuatan adonan kerupuk dengan ampas batang pisang dan tepung

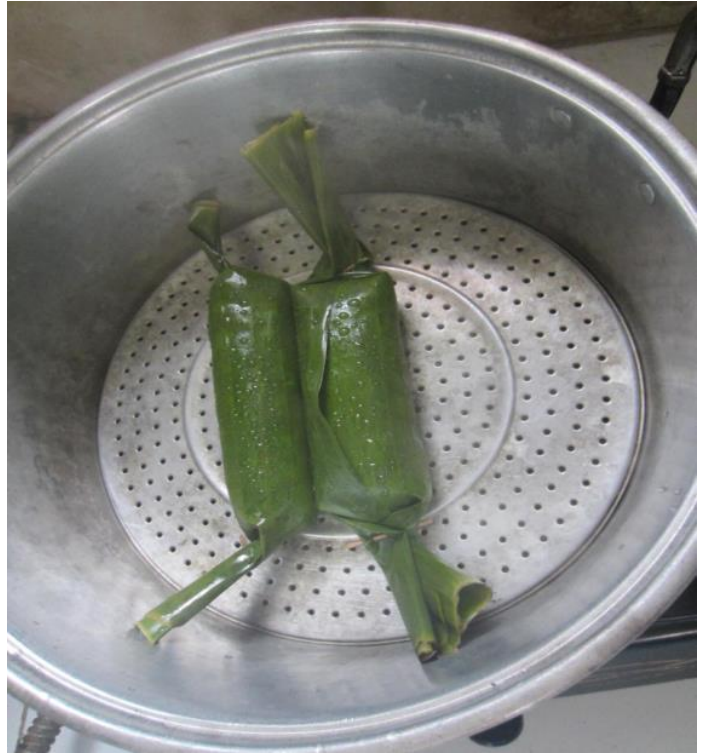

Adonan kerupuk yang telah dikukus, selanjutnya didiamkan semalam lalu dipotong

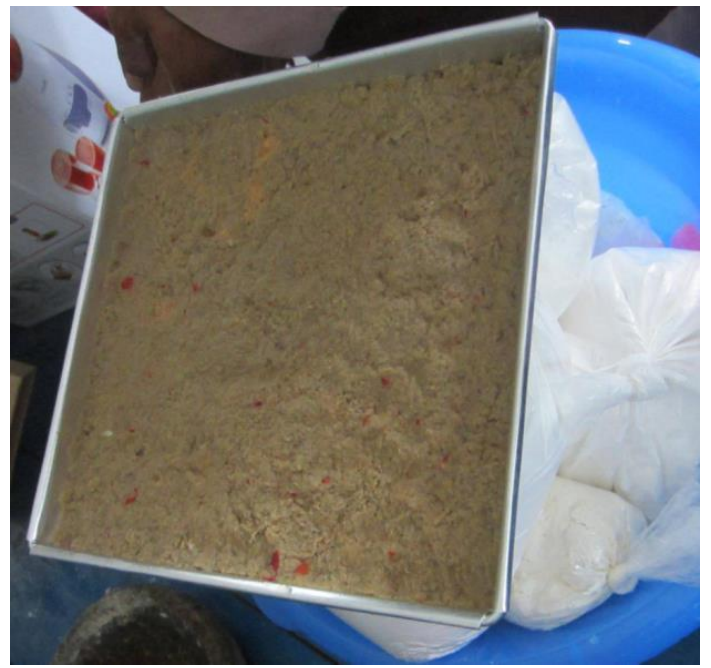

Adonan dendeng yang siap untuk dioven

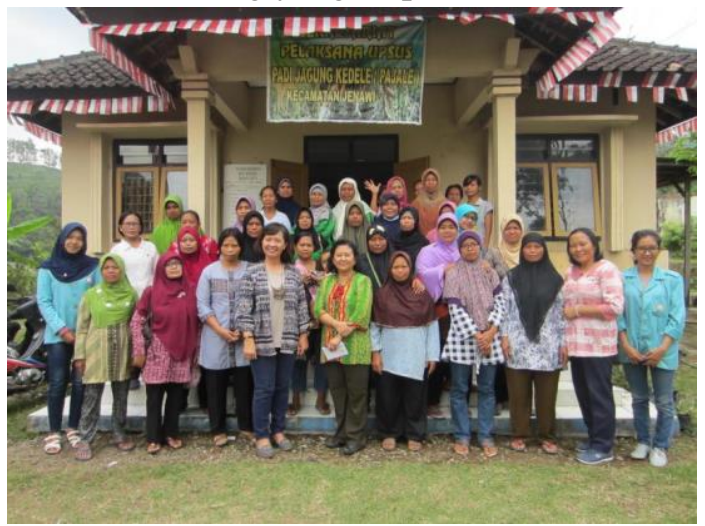

Foto bersama antara Tim Pengabdian dengan peserta pelatihan tahap 1 


\section{Pelatihan Tahap 2}

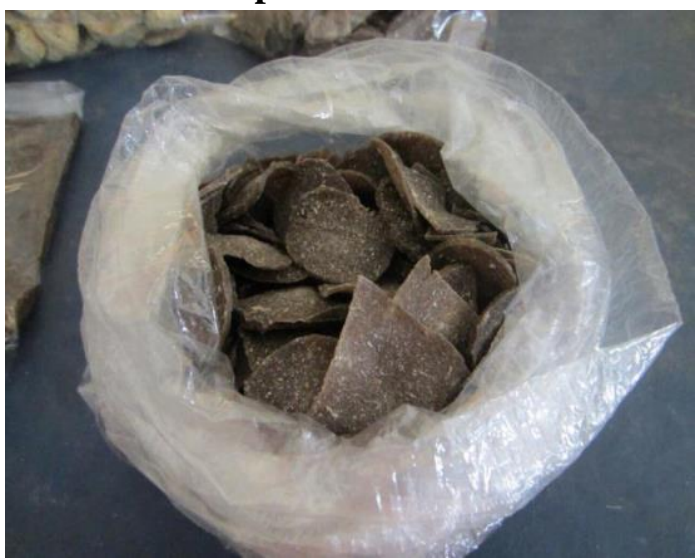

Gambar kerupuk hati bating pisang sebelum digoreng

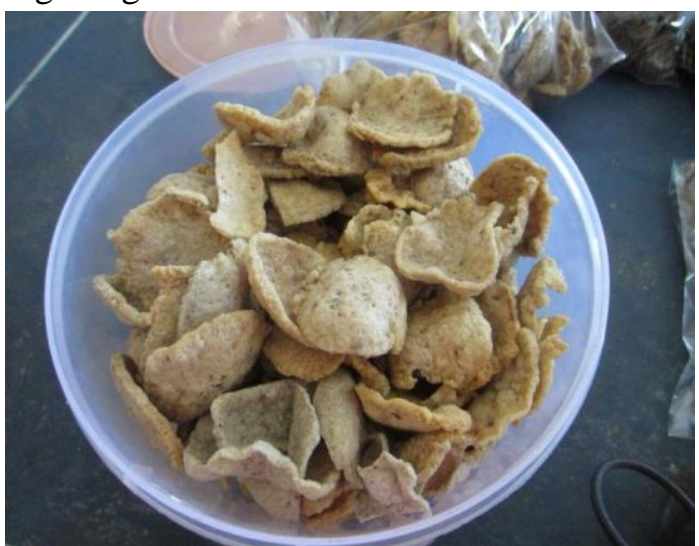

Gambar kerupuk hati batang pisang setelah digoreng

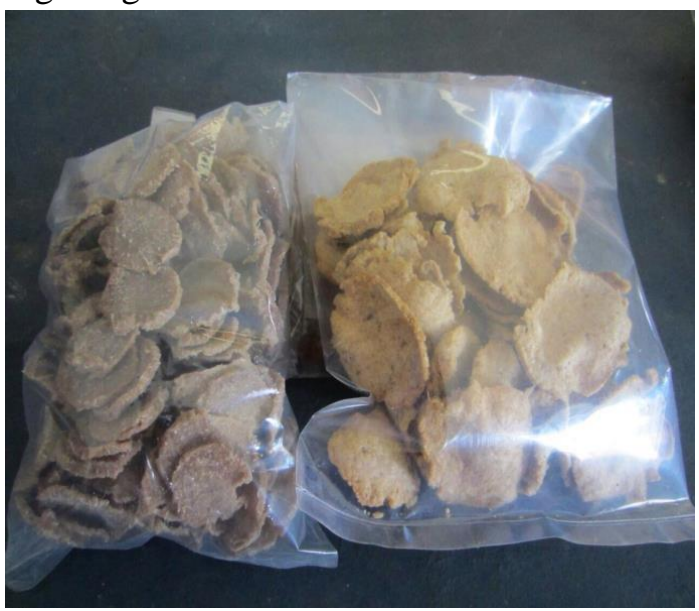

Gambar kerupuk hati batang pisang setelah digoreng dengan pengemasan sederhana

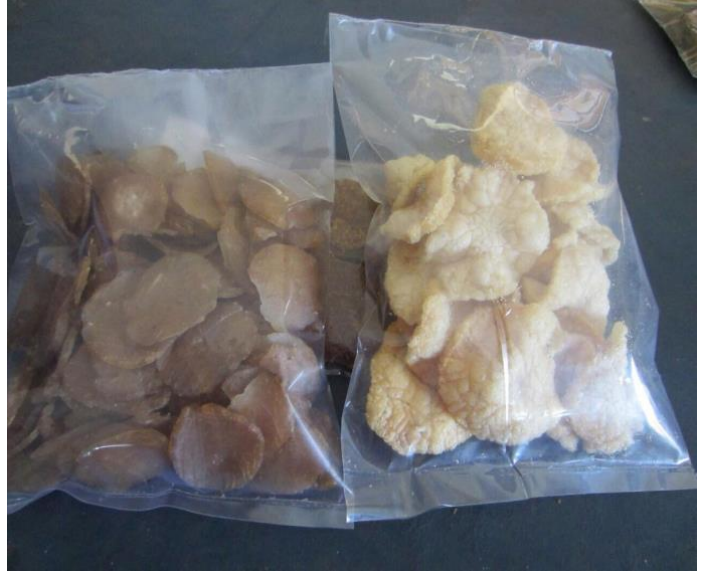

Gambar kerupuk hati batang pisang setelah digoreng dengan pengemasan sederhana

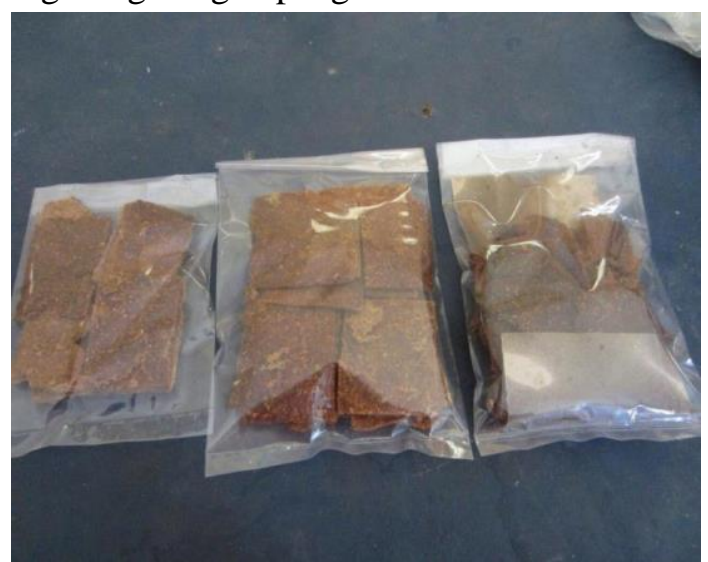

Gambar Dendeng hati batang pisang

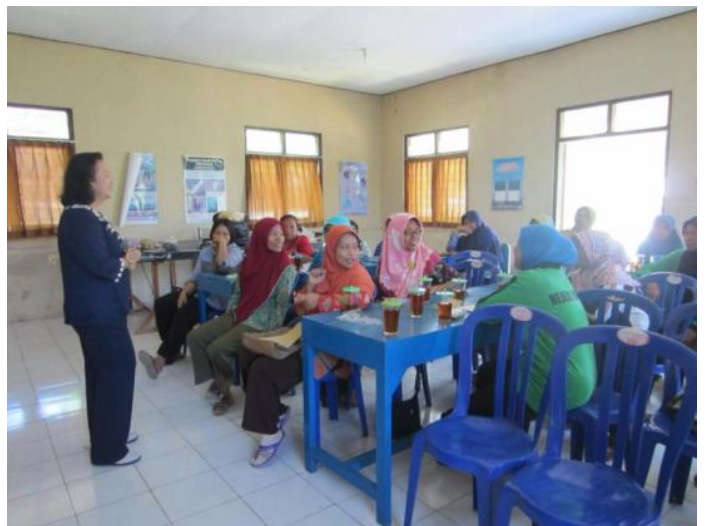

Gambar kegiatan pelatihan tahap 2 : monitoring dan uji kualitas produk 


\section{KESIMPULAN}

1. Pelaksanaan kegiatan ini diawali dengan identifikasi permasalahan dan kebutuhan masyarakat Kecamatan Jenawi, Kab. Karanganyar, Propinsi Jawa Tengah, dilanjutkan dengan membuat perencanaan sampai pelaksaaan kegiatan pembuatan kerupuk dan dendeng berbahan dasar ampas hati batang pisang

2. Kegiatan ini : a. mampu menawarkan alternatif pemanfaatan hasil pertanian menjadi produk pangan baru yang belum dikenal luas oleh masyarakat, b. meningkatkan ketrampilan masyarakat dalam pengolahan hasil pertanian menjadi produk pangan baru menggunakan teknologi sederhana, c. meningkatkan diversifikasi pemanfaatan tanaman pisang, d. meningkatkan nilai kemanfaatan dan ekonomis batang tanaman pisang, dari semula tidak lazim digunakan sebagai bahan baku makanan olahan menjadi bahan baku pembuatan kerupuk dan dendeng hati batang pisang yang bernilai ekonomis tinggi, e. meningkatkan pengetahuan dan ketrampilan masyarakat kecamatan Jenawi, Kab. Karanganyar dalam hal pemanfaatan hati batang pisang dan cara pengolahannya menjadi kerupuk dan dendeng hati batang pisang, menggunakan teknologi sederhana dan ramah Lingkungan, 6. membantu masyarakat kecamatan Jenawi dalam memanfaatkan bagian lain dari tanaman pisang, selain buahnya, sehingga dapat menjadi alternatif sumber mata pencaharian baru.

\section{SARAN}

1. Kegiatan pembuatan kerupuk dan dendeng hati batang pisang dapat dilaksanakan secara mandiri oleh masyarakat, khususnya masyarakat di Kecamatan Jenawi, Kab. Karanganyar, Propinsi Jawa Tengah

2. Adanya penyebarluasan teknologi tepat guna dan sederhana tentang pembuatan kerupuk dan dendeng hati batang pisang kepada masyarakat luas.

\section{DAFTAR PUSTAKA}

Anonim. 2015. 12 Manfaat Pohon Pisang Bagi Kehidupan Manusia. Manfaat.co.id/manfaat-pohon- pisang. Diakses : Kamis, 16 Februari 2017, Pk. 06.30

Afandi M. 2013.Kesehatan Serta Cara Penggunaannya.

http://www.munsypedia.com/2013/12/manfa at-buah-kulit-batang-hati-akar.html.

Diakses : Kamis, 16 Februari 2017.

\section{UCAPAN TERIMA KASIH}

Ucapan terima kasih disampaikan kepada Dirjen Pendidikan Tinggi Kementrian Riset dan Pendidikan Republik Indonesia yang telah mendanai kegiatan ini melalui Hibah Ipteks bagi Masyarakat tahun aggaran 2017. Juga disampaikan ucapan terima kasih kepada aparat pemerintah Kecamatan Jenawi, khususnya pimpinan dan staf Balai Penyuluh Pertanian atas ijin dan fasilitas yang diberikan, da anggota KWT Rejeki Mandiri serta KWT Mukti Rahayu atas kerjasama dan partisipasinya. 